\title{
Differential Expression of Prostaglandin I2 Synthase Associated with Arachidonic Acid Pathway in the Oral Squamous Cell Carcinoma
}

\author{
Anelise Russo ${ }^{D},{ }^{1}$ Patrícia M. Biselli-Chicote ${ }^{\mathbb{D}},{ }^{1}$ Rosa S. Kawasaki-Oyama, \\ Márcia M. U. Castanhole-Nunes, ${ }^{1}$ José V. Maniglia, ${ }^{2}$ Dalísio de Santi Neto, ${ }^{3}$ \\ Érika C. Pavarino $\mathbb{D},{ }^{1}$ and Eny M. Goloni-Bertollo $\mathbb{I D}^{1}$ \\ ${ }^{1}$ Department of Molecular Biology: Biological and Genetics and Molecular Biology Research Unit - UPGEM, \\ São José do Rio Preto Medical School - FAMERP, São José do Rio Preto, SP 15090-000, Brazil \\ ${ }^{2}$ Department of Otorhinolaryngology and Head and Neck Surgery, FAMERP, São José do Rio Preto, SP 15090-000, Brazil \\ ${ }^{3}$ Department of Pathology, FAMERP, São José do Rio Preto, SP 15090-000, Brazil
}

Correspondence should be addressed to Anelise Russo; aneliserusso@yahoo.com.br and Eny M. Goloni-Bertollo; eny.goloni@famerp.br

Received 17 July 2018; Accepted 16 October 2018; Published 8 November 2018

Academic Editor: Thomas R. Chauncey

Copyright (C) 2018 Anelise Russo et al. This is an open access article distributed under the Creative Commons Attribution License, which permits unrestricted use, distribution, and reproduction in any medium, provided the original work is properly cited.

\begin{abstract}
Introduction. Differential expression of genes encoding cytochrome P450 (CYP) and other oxygenases enzymes involved in biotransformation mechanisms of endogenous and exogenous compounds can lead to oral tumor development. Objective. We aimed to identify the expression profile of these genes, searching for susceptibility biomarkers in oral squamous cell carcinoma. Patients and Methods. Sixteen oral squamous cell carcinoma samples were included in this study (eight tumor and eight adjacent non-tumor tissues). Gene expression quantification was performed using TaqMan Array Human CYP450 and other Oxygenases 96-well plate (Applied Biosystems) by real time qPCR. Protein quantification was performed by ELISA and IHC methods. Bioinformatics tools were used to find metabolic pathways related to the enzymes encoded by differentially expressed genes. Results. CYP27B1, CYP27A1, CYP2E1, CYP2R1, CYP2J2, CYP2U1, CYP4F12, CYP4X1, CYP4B1, PTGIS, ALOX12, and MAOB genes presented differential expression in the oral tumors. After correction by multiple tests, only the PTGIS (Prostaglandin I2 Synthase) gene presented significant differential expression $(\mathrm{P}<0.05)$. The PTGIS gene and protein were reduced in oral tumors. Conclusion. PTGIS presents downexpression in oral tumors. PTGIS play an important role in the arachidonic acid metabolism. Arachidonic acid and/or metabolites are derived from this pathway, which can influence the regulation of important physiological mechanisms in tumorigenesis process.
\end{abstract}

\section{Introduction}

Worldwide, approximately 600,000 new cases of head and neck cancer HNC are diagnosed each year, and oral cancer comprises about half of these cases and is considered the most representative site of this tumor type [1]. In Brazil, the National Cancer Institute (INCA) estimates for each year of the biennium 2018-2019 that there are, 14,700 new cases of oral cavity cancer, representing the fifth-most-common cancer in men with 11,200 new cases. Regarding females, it was estimated that there are 3,500 new cases [2].
Literature data also show a high prevalence of oral cancer, which has been attributed to oral sex leading to increased infection with human papilloma virus (HPV) $[3,4]$. This virus can be related to oxidative stress changes in saliva [5] as a reduction of antioxidant mechanism, increased reactive oxygen species (ROS) [6], and reactive nitrogen species (RNS), which leads to damage to DNA [7-9]. These changes prevent the antioxidative system of saliva from exercising its protective function, allowing carcinogenic compounds to act in the oral cavity [5]. Xenobiotic compounds such as $\mathrm{N}$-nitrosamines, polycyclic aromatic hydrocarbons (HPAs) 
from tobacco $[10,11]$, and acetaldehyde, the primary metabolite of alcohol $[12,13]$, bind to DNA to form stable adducts [9].

Genes encoding enzymes involved in the activation mechanism and subsequent detoxification of carcinogenic compounds can present genetic polymorphisms $[8,14-20]$ that can modulate the gene expression, [21] leading to cancer development $[21,22]$.

CYP450 enzymes are monooxygenases functionally related to other oxygenases, such as monoamine oxygenase and the lipoxygenase family [23, 24]. In addition to participating in the pathway of xenobiotics, monooxygenases catalyze reactions in which a hydroxyl group is added to the protein, lipid, or other ligand. Members of this family participate in both biosynthesis and degradation of steroids, vitamins, fatty acids, arachidonic acid, prostaglandins, amines, pheromones, and plant metabolites [21, 24-26]. They also metabolize several drugs and chemical carcinogens/mutagens, among other environmental pollutants denominated as xenobiotics [27-29].

Thus, enzymes involved in xenobiotic biotransformation pathways can participate indirectly in the carcinogenesis mechanism due to their major role in individual susceptibility to disease, as they are responsible for the activation and detoxification of these compounds [21, 22]. For this reason, studies have been conducted to verify the association between the expression of genes encoding those enzymes and oral squamous cell carcinoma (OSCC) $[30,31]$, which accounts for $90 \%$ of malignant oral cancers [32]. However, there are very few studies on genome-wide profiling of OSCC tumors.

Considering the evidence presented, this study was designed to investigate the expression pattern of genes and proteins of the CYP450 family and other oxygenases involved in the biotransformation mechanism of endogenous compounds and xenobiotics in OSCC and compare them to adjacent non-tumor tissues. Moreover, the study was designed to identify the metabolic pathways related to genes differentially expressed in OSCC, enabling establishment of the importance of these genes in the carcinogenesis of OSCC.

\section{Patients and Methods}

This study is in accordance with the regulations of Resolution 466/12 of the National Health Council and was approved by the Committee of Ethics in Research-São José do Rio Preto Medical School (CEP-FAMERP), No. 216,758.

2.1. Samples Characterization. After informed consent, eight samples of tumor tissue and the adjacent non-tumor tissues of patients with OSCC coming from Otorhinolaryngology and Head and Neck Surgery of Hospital Base, Complex FAMERP/FUNFARME, were included in the study.

Inclusion criteria of samples in the study were pathological confirmation of primary tumor tissue of OSCC and adjacent non-tumor tissue, negative diagnosis for HPV 16 and 18 types, and sufficient concentration for quantification of gene expression. The exclusion criteria were tumor from relapse or patients treated with radiotherapy and/or chemotherapy before surgery.

Tumors were classified by the medical team participant of this study according to the parameters of Oncology Manual, Union for International Control Cancer (UICC), and the American Joint Committee for Cancer (AJCC) [33-35] on three criteria: tumor extension $(\mathrm{T})$, nodal metastasis $(\mathrm{N})$, and distant metastasis (M). T classification was divided into smaller (T1, T2) and larger (T3, T4) tumors. The N classification was defined as absence (N0) and presence (N1, N2, N3) of nodal metastasis. M classification was dichotomized in absence (M0) or presence (M1) of distant metastasis. The stages were divided into early (stages I and II) and advanced disease (III and IV) [33-35]. The diagnosis, primary tumor site, TNM classification, and some clinical information were obtained from medical records of the patients included in the study.

The study consisted of male patients with mean age of 68.25 years $( \pm 10.30)$. Regarding the TNM, $50 \%$ of the tumors presented larger extension, $62.5 \%$ had nodal metastasis, and $62.5 \%$ had an absence of distant metastasis. In relation to tumor progression, $37.5 \%$ of cases were classified as nonadvanced tumors (stages I and II) and $62.5 \%$ of cases as advanced tumors (stages III and IV).

2.2. Molecular Analysis. OSCC and adjacent non-tumor tissues were immediately stored in liquid nitrogen for transport and subsequently stored in a freezer at $-80^{\circ} \mathrm{C}$ until processing. Genomic DNA and total RNA were extracted by sequential extraction methodology with TRIzol ${ }^{\circledR}$ Reagent (Ambion, Austin, TX), and the extracted total RNA was purified using the mirVana ${ }^{\mathrm{TM}}$ PARIS $^{\mathrm{TM}}$ Kit (Applied Biosystems, Foster City, $\mathrm{CA}$ ), according to manufacturer instructions.

According to literature data, the HPV16 and HPV18 types, which present E6 and E7 oncogenes, can participate in oral cavity carcinogenesis [36-40]. The detection of HPV16 and HPV18 by real-time Polymerase Chain Reaction (PCR) was performed from genomic DNA in collaboration with the "Instituto de Medicina Tropical de São Paulo-Universidade de São Paulo (USP)" [41, 42].

The purified total RNA samples were submitted to Reverse Transcription-Polymerase Chain Reaction (RTPCR) for complementary DNA (cDNA) synthesis using the High-Capacity cDNA Reverse Transcription ${ }^{\circledR}$ (Applied Biosystems, Foster City, CA) according to manufacturer instructions.

In the present study, the standard curve was performed with GAPDH and HPRT1 reference genes to analysis of efficiency and determine the amount of sample to be used in the reactions.

Gene expression quantification of genes involved in biotransformation mechanism of endogenous and exogenous compounds was performed using the TaqMan ${ }^{\circledR}$ Array Human CYP450 and other Oxygenases, Fast 96-well Plate (Applied Biosystems, Foster City, CA-catalogue number 4418730 ) by quantitative real-time PCR (qPCR). The panel of assays designed by the manufacturer allowed the evaluation of four reference genes (RNA, 18S ribosomal (18S), 


\begin{tabular}{|l|c|c|c|c|c|c|c|c|c|c|c|c|}
\hline Gene & $\mathbf{1}$ & $\mathbf{2}$ & $\mathbf{3}$ & $\mathbf{4}$ & $\mathbf{5}$ & $\mathbf{6}$ & $\mathbf{7}$ & $\mathbf{8}$ & $\mathbf{9}$ & $\mathbf{1 0}$ & $\mathbf{1 1}$ & $\mathbf{1 2}$ \\
\hline $\mathbf{A}$ & $18 S$ & $G A P D H$ & HPRT1 & GUSB & CYP1A1 & CYP1A2 & CYP1B1 & CYP11A1 & CYP11B1 & CYP11B2 & CYP17A1 & CYP19A1 \\
\hline $\mathbf{B}$ & CYP2A13 & CYP2A6 & CYP2A7 & CYP2B6 & CYP2C18 & CYP2C19 & CYP2C8 & CYP2C9 & CYP2D6 & CYP2E1 & CYP2F1 & CYP2J2 \\
\hline $\mathbf{C}$ & CYP2R1 & CYP2S1 & CYP2U1 & CYP2W1 & CYP3A4 & CYP3A43 & CYP3A5 & CYP3A7 & $\begin{array}{l}\text { CYP4A11 } \\
\text { CYP4A22 }\end{array}$ & CYP4B1 & CYP4F11 & CYP4F12 \\
\hline $\mathbf{D}$ & CYP4F2 & CYP4F22 & CYP4F3 & CYP4F8 & CYP4V2 & CYP4X1 & CYP4Z1 & CYP7A1 & CYP7B1 & CYP8B1 & CYP20A1 & CYP21A2 \\
\hline $\mathbf{E}$ & CYP24A1 & CYP26A1 & CYP26B1 & CYP26C1 & CYP27A1 & CYP27B1 & CYP27C1 & CYP39A1 & CYP46A1 & CYP51A1 & TBXAS1 & PTGIS \\
\hline $\mathbf{F}$ & ORC3L & CYB5A & CYB5B & CYB5R1 & CYB5R2 & CYB5R3 & CYB5R4 & FDX1 & FDXR & FLAD1 & NENF & PGRMC1 \\
\hline $\mathbf{G}$ & PGRMC2 & BCMO1 & DBH & DOHH & $F M O 1$ & $F M O 2$ & $F M O 3$ & $F M O 4$ & FMO5 & KMO & PAH & PAM \\
\hline $\mathbf{H}$ & $S C 4 M O L$ & $S Q L E$ & $T H$ & $T P H 1$ & $T P H 2$ & $T Y R$ & MAOA & MAOB & ALOXE3 & ALOX5 & ALOX12 & ALOX15 \\
\hline
\end{tabular}

Reference genes

CYP450 and other Oxygenase genes

Figure 1: Graphical representation of the TaqMan ${ }^{\circledR}$ Array Human CYP450 and other Oxygenases 96-well Plate.

glyceraldehyde-3-phosphate dehydrogenase (GAPDH), hypoxanthine phosphoribosyltransferase 1 (HPRT1), and glucuronidase, beta (GUSB)) as endogenous controls, 92 genes of the CYP450 family, and other oxygenases such as monoamine oxygenases and lipooxygenases (Figure 1). The reactions were performed in duplicate with $25 \mathrm{ng}$ of cDNA on StepOnePlusTM Real-Time PCR System (Applied Biosystems, Foster City, CA) and cycled at $50^{\circ} \mathrm{C}$ for 2 minutes, $95^{\circ} \mathrm{C}$ for 10 minutes followed by 40 cycles at $95^{\circ} \mathrm{C}$ for 15 seconds and $60^{\circ} \mathrm{C}$ for 1 minute.

Raw qPCR data (quantification cycle values) were calculated by ExpressionSuite software version 1.0.3 (Applied Biosystems, Foster City, CA) after manual adjustment of the basal fluorescence signal (baseline) and the threshold for each gene analyzed.

For normalization of gene quantification data, the geometric mean of multiple reference genes was used [43]. The calculation of relative quantification (RQ) was performed, using samples of non-tumor tissue as calibrators, by the $2^{-\Delta \Delta \mathrm{Cq}}$ method [44-46].

2.3. Bioinformatic Analysis of Differentially Expressed Genes. The bioinformatics tools the Kyoto Encyclopedia of Genes and Genomes (KEGG) [47], the Search Tool for the Retrieval of Interacting Genes/Proteins Information (STRING) [48], the National Center for Biotechnology (NCBI) [49], GeneCards ${ }^{\circledR}$ : The Human Gene Database [50], "Descritores em Ciências da Saúde" (DeCS) [51], Protein knowledgebase (UniProtKB) [52], and European Molecular Biology Laboratory-The European Bioinformatic Institute (EMBL-EBI) [53] were used to investigate the biological functions and metabolisms in which the enzymes encoded by differentially expressed genes are involved.

2.4. Protein Quantification. Among the differentially expressed genes, five were selected (CYP2E1, CYP2J2, CYP2U1, ALOX12B, and PTGIS) for protein quantification.
For protein extraction, OSCC and adjacent non-tumor fragment tissues were washed with Phosphate Buffered Saline (PBS) $1 \mathrm{X}$ at 7.0-7.2 pH. Subsequently, the fragment was shredded into small pieces in a PBSIX buffer and taken to the sonicator with pulse 3 for 30 seconds in 3 cycles, with an interval of 1 minute between cycles, followed by centrifugation of $5,000 \mathrm{rpm}$ for 15 minutes at $4^{\circ} \mathrm{C}$. The proteins were quantified by BCA kit (Thermo Fisher) in a microplate reader at $562 \mathrm{~nm}$ filter.

2.5. Enzyme-Linked Immunosorbent Assay (ELISA). Comparison of protein concentration between tumors and non-tumor tissues was performed by Enzyme-Linked Immunosorbent Assay (ELISA) using CYP2E1, CYP2J2, CYP2U1, ALOX12B, and PTGIS BioAssay ${ }^{\mathrm{TM}}$ ELISA kit (United States Biological, Life Science Massachusetts, USA) according to the manufacturer instructions. Reactions were performed using 10 ug of total protein and quantified in a microplate reader at $450 \mathrm{~nm}$ filter.

2.6. Immunohistochemistry (IHC). Immunohistochemistry was carried out on three-micrometer thick sections of the OSCC tumors paraffin blocks. Non-tumor tissue margins were used as reference expressions.

Immunohistochemistry analysis was possible for ALOX12B and PTGIS proteins using the REVEAL BiotinFree Detection System (Spring Bioscience, Pleasanton, CA) with primary antibodies: Anti-PTGIS antibody ab23668 (dilution 1:500; Abcam, Cambridge, UK) and ALOX12B antibody NBP1-89409 (dilution 1:500; Novus biologicals, Colorado, USA) incubated overnight at $4^{\circ} \mathrm{C}$. For ALOX12B, after the endogenous peroxidase blocking step, the tissue permeabilization was carried out, in which washes were performed in 1X PBS with $0.025 \%$ of Triton X-100 for 10 minutes at room temperature. At the end, the slides were mounted in Entellan (Merck, Darmstadt, Germany). 


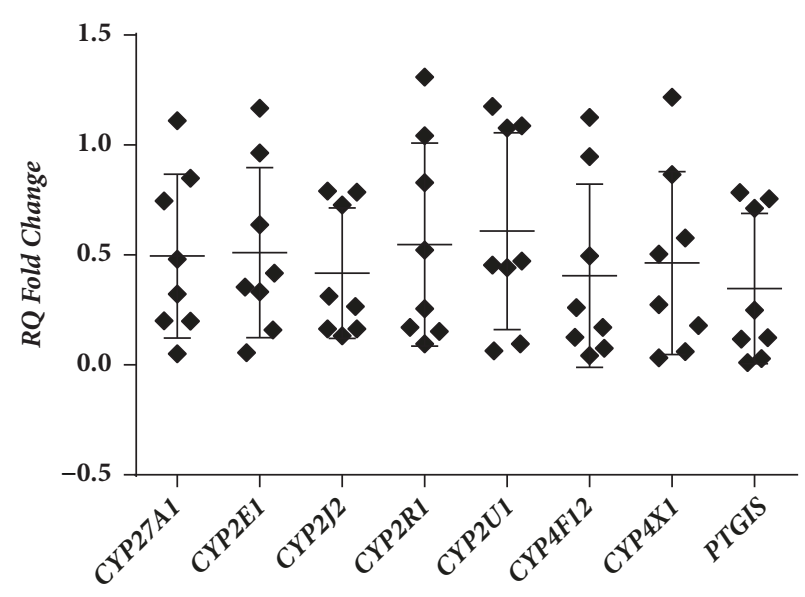

(a)

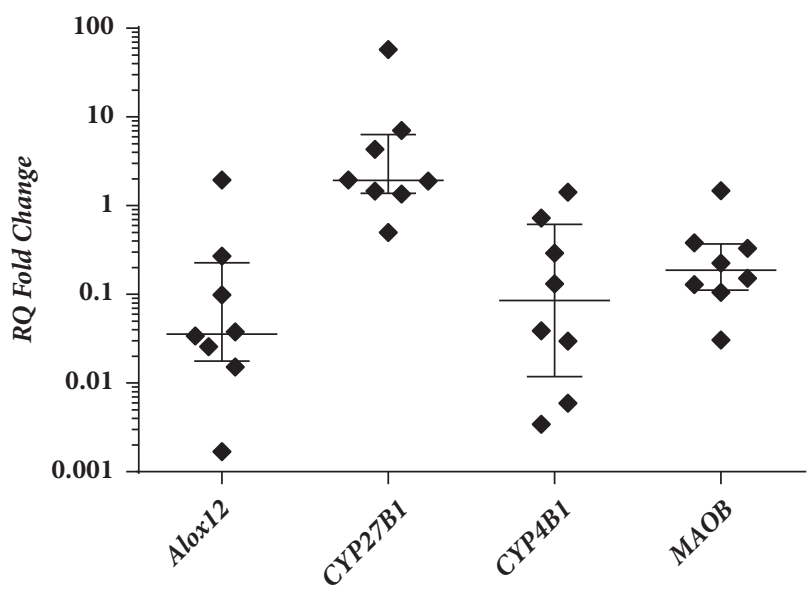

(b)

Figure 2: Gene expression in oral tumors in relation to non-tumor tissues. (a) Genes analyzed by One Sample T Test (mean with standard deviation). The RQ values are presented in linear scale. (b) Genes analyzed by Wilcoxon signed rank test (median with interquartile variation). The RQ values are shown in base 10 logarithmic scale.

Slides with OSCC and non-tumor tissues were photographed, and protein expression was evaluated by the average of score values from 0 to 4 (score 0 : $0-5 \%$, score 1: $5-25 \%$, score $2: 25-50 \%$, score $3: 50-75 \%$ and score 4 : $75-100 \%)$ according to staining.

2.7. Statistical Analysis. The D'Agostino \& Pearson omnibus normality test was performed to evaluate normal distribution of the data. Relative gene quantification was performed by One-sample $\mathrm{T}$ test or Wilcoxon signed rank test. Correction for multiple tests described by Benjamini and Hochberg (1995) (Benjamini-Hochberg False Discovery Rate) was applied to correct the occurrence of false positives [54]. ELISA and Immunohistochemistry data were evaluated by $\mathrm{T}$ test, Mann Whitney test, or Wilcoxon matched-paired test. The correlation between gene expression and protein expression values was conducted by Pearson or Spearman correlation test. $p$ values $<0.05$ were considered significant, and statistical analyses were performed using GraphPad Prism v.5 and StatsDirect v.2.7.2 programs.

\section{Results}

Our results showed that 12 genes showed differential expression in OSCC tissues compared to adjacent non-tumor tissues $(P<0.05)$. The CYP27B1 gene showed overexpression in OSCC, while CYP27A1, CYP2E1, CYP2R1, CYP2J2, CYP2U1, CYP4F12, CYP4X1, CYP4B1, PTGIS, ALOX12B, and MAOB genes showed reduced expression (Table 1 and Figure 2). After correction for multiple tests of the Benjamini-Hochberg False Discovery Rate, the PTGIS gene showed significantly different expression levels.

The 12 differentially expressed genes were related to 24 metabolic pathways of the Human species (Table 2). Among them, 12 pathways were associated with the carcinogenesis process, highlighting the arachidonic acid metabolism, in which five of the differentially expressed genes in OSCC (ALOX12, CYP2E1, CYP2J2, CYP2U1, and PTGIS) act. Because the role of arachidonic acid metabolism was representative in this study, the proteins encoded by these genes were selected for protein analysis by ELISA and IHC [47].

The results of protein analysis by ELISA showed that expression of ALOX12 (median: $\mathrm{OSCC}=12.09 \mathrm{ng} / \mu \mathrm{L}$ vs. nontumor $=15.80 \mathrm{ng} / \mu \mathrm{L}$ ), CYP2E1 (median: OSCC $=0.046 \mathrm{ng} / \mu \mathrm{L}$ vs. non-tumor $=0.053 \mathrm{ng} / \mu \mathrm{L}$ ), CYP2J2 (median: OSCC = $21.91 \mathrm{ng} / \mu \mathrm{L}$ vs. non-tumor $=21.34 \mathrm{ng} / \mu \mathrm{L})$, and CYP2U1 (mean: OSCC $=11.95 \mathrm{ng} / \mu \mathrm{L}$ vs. non-tumor $=14.57 \mathrm{ng} / \mu \mathrm{L}$ ) proteins were not statistically different between OSCC and non-tumor tissues $(\mathrm{p}>0.05)$, although the lower expression was observed in tumors. PTGIS protein showed significantly reduced expression in OSCC (median: $\mathrm{OSCC}=1.58 \mathrm{ng} / \mu \mathrm{L}$ vs. non-tumor $=2.80 \mathrm{ng} / \mu \mathrm{L} ; \mathrm{p}=0.0156)($ Figure 3$)$.

Expression of ALOX12, CYP2E1, CYP2J2, CYP2U1, and $P T G I S$ genes were not correlated to expression of the respective proteins in OSCC $(\mathrm{p}=0.243 ; \mathrm{p}=0.8397 ; \mathrm{p}=0.95 ; \mathrm{p}=$ 0.4256 e $\mathrm{p}=0.2430$, respectively).

IHC results showed that ALOX12B and PTGIS proteins presented low expression in groups of OSCC and non-tumor tissues (Figure 4).

Regarding clinical and histopathological parameters of tumor we did not find statistical significance between reduced expression of CYP27A1, CYP2E1, CYP2R1, CYP2J2, CYPU1, CYP4F12, CYP4X1, CYP4B1, PTGIS, ALOX12, and MAOB genes and increased expression of $C Y P 27 B 1$ gene with tumor extension, nodal metastasis, and tumor progression in OSCC development.

\section{Discussion}

In the present study, differential expression was observed for 12 genes in OSCC compared to adjacent non-tumor tissues. CYP27A1, CYP2E1, CYP2R1, CYP2J2, CYP2U1, CYP4F12, 


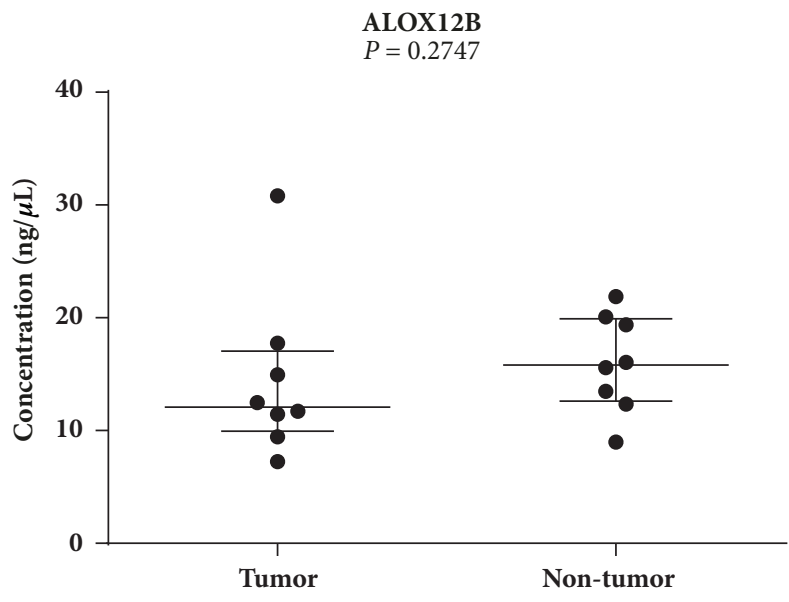

(a)

CYP2J2

$P=0.9307$

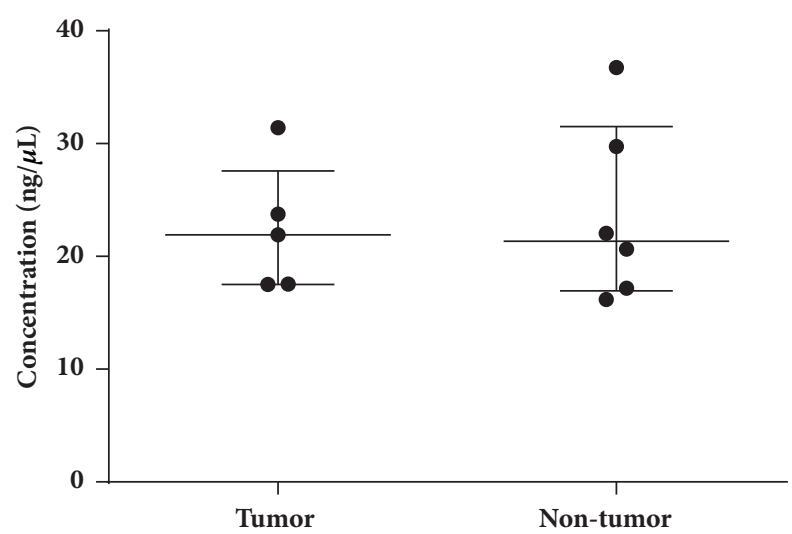

(c)

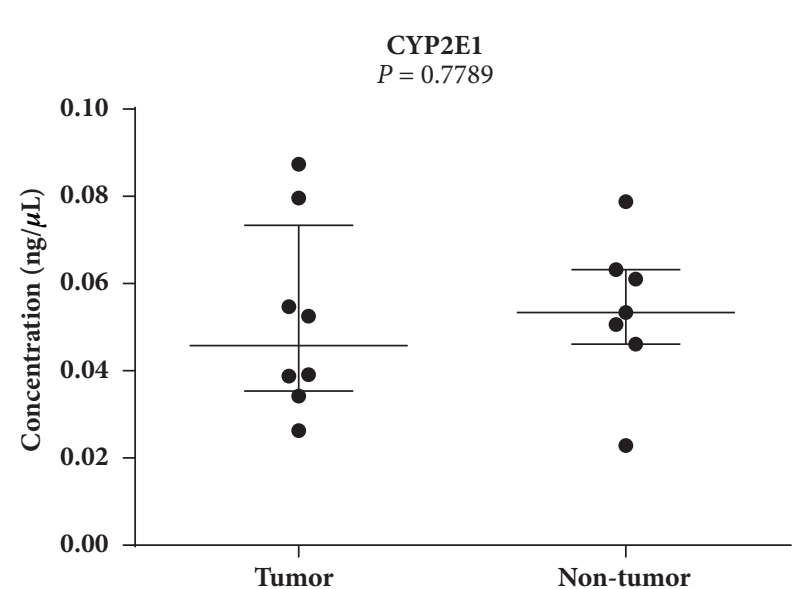

(b)

CYP2U1

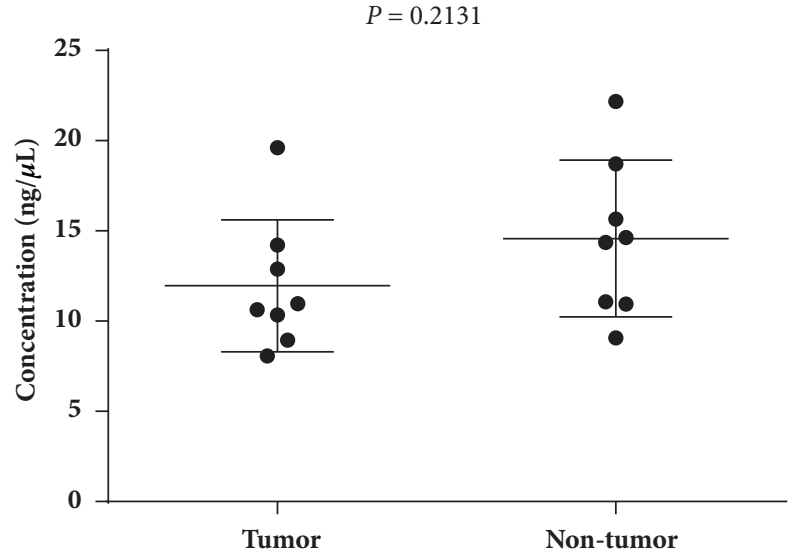

(d)

PTGIS

$P=0.0156$

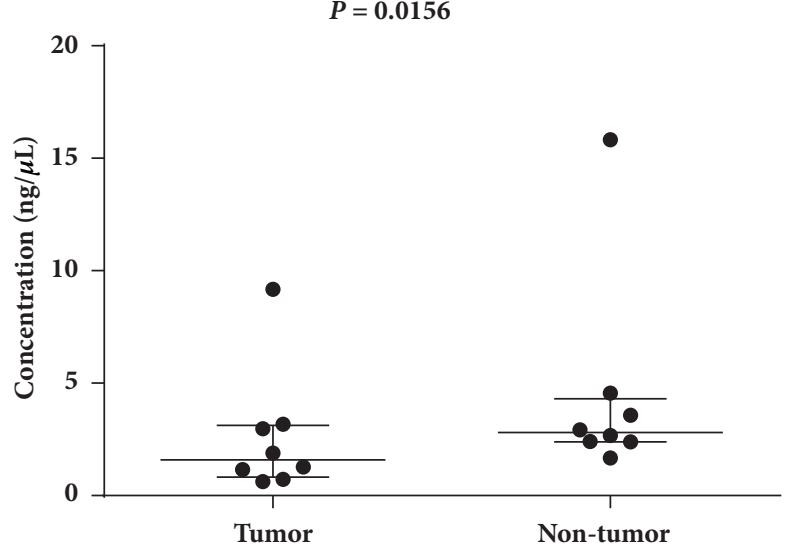

(e)

Figure 3: Protein expression by ELISA assay in oral tumors compared to non-tumor tissues. (a), (b) and (c) Results of Mann Whitney test (median with interquartile variation). (d) Results of Unpaired T test (mean with standard deviation). (e) Results of Wilcoxon matched paired test (median with interquartile variation), in bold the statistically significant $\mathrm{p}$ value. The concentration values of proteins are presented in linear scale. 


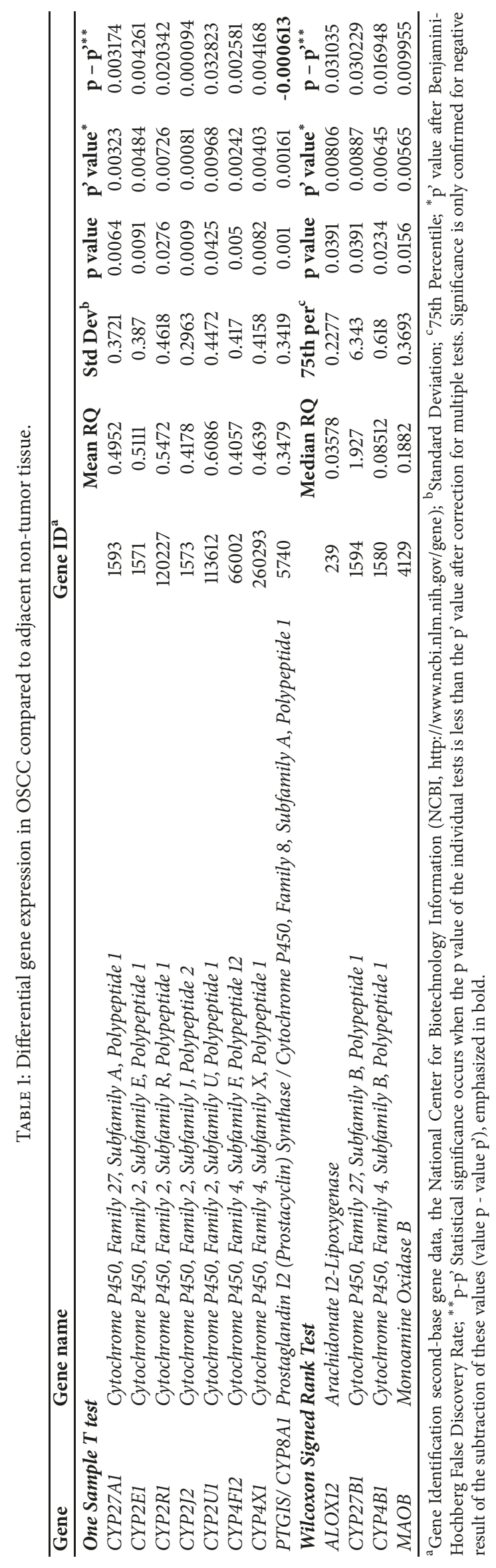


I

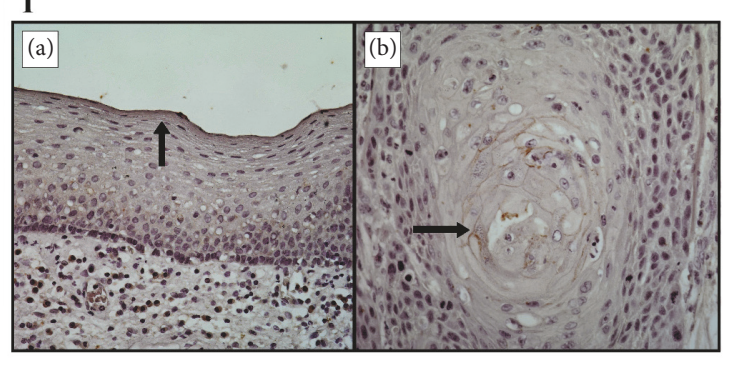

II

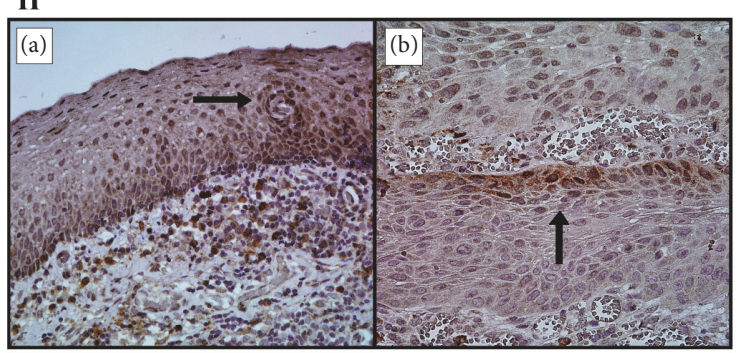

FIgUre 4: Analysis of ALOX12B and PTGIS proteins expression in tumor and non-tumor tissue by Immunohistochemistry. I: Expression of ALOX12B protein; the arrows show weak labeling (brown staining) of non-tumor squamous cells in (a) and OSCC cells in (b). II: Expression of PTGIS protein; the arrows show moderate labeling (brown staining) of non-tumor squamous cells in (a) and weak labeling of OSCC cells in (b).

TABLE 2: The metabolic pathways of Human species related to the 12 differentially expressed genes in OSCC.

\begin{tabular}{lc}
\hline Human metabolic pathways & Genes \\
\hline Metabolism of xenobiotics by cytochrome P450 & CYP2E1, CYP4B1 and CYP4F12 \\
\hline Chemical carcinogenesis & CYP2E1 and CYP4B1 \\
\hline Drug metabolism by cytochrome P450 & CYP2E1, MAOB, CYP4B1 and CYP4F12 \\
\hline Serotonergic synapse & ALOX12, CYP2J2, CYP4X1 and MAOB \\
\hline Arachidonic acid metabolism & ALOX12, CYP2E1, CYP2J2, CYP2U1, CYP4F12 and PTGIS \\
\hline Inflammatory mediator regulation of TRP ${ }^{\text {a }}$ channels & ALOX12 and CYP2J2 \\
\hline PPAR ${ }^{\text {s signaling pathway }}$ & CYP27A1 \\
\hline Steroid biosynthesis & CYP2R1 and CYP27B1 \\
\hline Steroid hormone biosynthesis & CYP2E1 \\
\hline Primary bile acid biosynthesis & CYP27A1 \\
\hline Linoleic acid metabolism & CYP2E1 and CYP2J2 \\
\hline Amino acids metabolism ${ }^{c}$ & MAOB \\
\hline Ovarian steroidogenesis & CYP2J2 \\
\hline Tuberculosis & CYP27B1 \\
\hline Nonalcoholic fatty liver disease (NAFLD) & CYP2E1 \\
\hline Dopaminergic synapse & MAOB \\
\hline Amphetamine, cocaine, and alcohol addiction & MAOB
\end{tabular}

${ }^{a}$ TRP: Transient Receptor Potential; ${ }^{b}$ PPAR: Peroxisome Proliferator Activated Receptors. ${ }^{c}$ The amino acids include glycine, serine, threonine, tyrosine, tryptophan, histidine, arginine, proline, and phenylalanine.

CYP4X1, CYP4B1, PTGIS or CYP8A1, ALOX12, and MAOB genes presented reduced expression, while the $C Y P 27 B 1$ gene showed increased expression in OSCC. Of the 24 pathways in which the enzymes encoded by these genes participate, 12 have been associated with carcinogenesis.

Differentially expressed genes encode enzymes of the cytochrome 450 monooxygenases (CYP450) family and other oxygenases as arachidonate lipoxygenase (ALOX) and monoamine oxidase (MAO). These enzymes play a role in oxidation reactions by adding one or more hydroxyl or oxygen molecules into the protein, lipid, or other ligand [50]. According to the literature, alteration in expression of these enzymes can be associated with oral carcinogenesis [30, 55, 56].

The metabolic pathways, in which the enzymes encoded by differentially expressed genes participate, can be involved in carcinogenesis highlighting the arachidonic acid metabolism (AA), the only pathway in which the protein encoded by the PTGIS gene (that remained significant after correction for multiple tests) participates.

In the AA metabolic pathway, PTGIS or CYP8A1 enzymes play a role catalyzing the conversion of prostaglandin $\mathrm{H} 2$ into prostacyclin (prostaglandin I2) [49]. The prostaglandin metabolic pathways have been involved in the inflammatory response [57] of important processes for the development of different types of cancers [58] by AA, a polyunsaturated fatty acid (PUFA) [59]. The AA, when oxygenated, is transformed into products that mediate or modify inflammatory reactions [59], and thus, it can activate or inhibit other pathways related to carcinogenesis [24,60]. In addition to inflammation, production of metabolites derived from PTGIS-mediated reactions regulate physiological processes including angiogenesis, coagulation, proliferation, and immune response [24, $57,61]$. 
Studies have shown that the PTGIS enzyme is associated with the progression of cancer [61, 62]. Regarding the head and neck squamous-cell carcinoma type (HNSCC), a study has investigated carbaprostacyclin $\left(\mathrm{CPGI}_{2}\right)$, a stable analogue of PTGIS, and showed little effect of analogue in cell migration of the HNSCC cell line. Furthermore, the authors suggested that the effect of PTGIS was related to its ability to promote vascularization; also, PTGIS gene and protein expression were shown to be reduced in HNSCC samples compared to non-tumor mucosa [63].

Our findings regarding reduced expression of the PTGIS gene and protein in patients with OSCC corroborate Camacho et al., who showed that this pathway could have contributed to the oral carcinogenesis in the present study. Reduction of PTGIS expression can modulate its possible anti-tumor functions [61] and contribute to carcinogenesis.

In addition to PTGIS, other genes of the CYP450 superfamily are involved in the AA metabolism, such as CYP2E1, CYP2J2, CYP2U1 (KEGG, 2015), CYP4F12 [52], and CYP4B1 [64] genes. Cyclooxygenase (COX), arachidonate lipoxygenase (ALOX), and CYP450 epoxygenases enzymes use the AA as a primary precursor, generating eicosanoids including prostaglandins, leukotrienes, epoxyeicosatrienoic acids (EETs), and hydroperoxyeicosatetraenic acids (HPETEs) [65].

In this metabolism, CYP2E1, CYP2J2, and CYP2U1 enzymes generate 19-HPETE, CYP2J2 generates EETs, and CYP4F12 converts arachidonic acid to a cis-EET and dihydroxyeicosatrienoic acids (DHET) [53]. In addition, rabbit CYP4B1 has been shown to generate 12(R)-hydroxyeicosatetraenoic acid (12(R)-HETE) and 12-hydroxyeicosatrienoic acid (12-HETrE), inflammatory mediators, from arachidonic acid in an NADPH-dependent manner [64]. Although the role of CYP4B1 is unclear in humans, in the cancer community, there is a potential therapeutic strategy involving prodrug activation by the CYP4B1 transgene [66].

ALOX12 enzyme also participates in AA metabolism, and it regulates biological processes including platelet activation, angiogenesis induced by Vascular Endothelial Growth Factor $(V E G F)$, apoptosis promoting the survival of vascular cells and control of cell migration and proliferation [49]. The ALOX12B enzyme can be procarcinogenic, as it converts AA in 12-HPETE and increases expression of encoding genes of proinflammatory cytokines such as Tumor Necrosis Factor $(\mathrm{TNF}-\alpha)[67,68]$.

Also acting within AA metabolism, ALOX12B and CYP2J2 enzymes perform the same function of generating 12-HPETE and EETs, respectively, from AA in the pathway of inflammatory mediator regulation of the Transient Receptor Potential (TRP) channels [47]. The TRP proteins of this pathway are cationic channels activated by 12-HPETE and EETs and belong to the molecular sensors superfamily that allows detection of environmental stimulus and promotes the senses [69]. The OSCC cell line has been observed with increased expression of Transient Receptor Potencial Vanilloid (TRPV1), which is activated by HPETE (a product of ALOX12B-mediated reactions). Furthermore, TRPV1 overexpression was associated with accelerated growth of these cells [70]. However, in patients with OSCC in our study, the $A L O X 12 B$ gene showed reduced expression.

The metabolites derived from AA metabolism generated by CYP450, ALOX, and PTGIS also act, activating the Peroxisome Proliferator Activated Receptors (PPAR) [47]. This pathway promotes the signaling of transcription factors that regulate the expression of genes involved in lipid oxidation, inflammation, proliferation, and cell migration associated with tumorigenesis [71-73]. In this study, reduced expression of CYP450, ALOX, and PTGIS genes could be associated with the reduction of $C Y P 27 A 1$ gene expression in oral tumors investigated, since the PPAR activation promotes CYP27A1 gene expression.

CYP27A1 enzyme metabolizes cholesterol [47]. Cholesterol is derived from the vitamin D3-dependent steroid biosynthetic pathway, and it can be metabolized by the CYP27A1 enzyme in primary bile acid biosynthesis, used in steroid hormone biosynthesis, which also operates the CYP2E1 enzyme, or even directed to the degradation pathway of steroid [47].

Regarding primary bile acid biosynthesis, recent studies have revealed that the bile acid lithocholic type displays a significant cytotoxic effect on cancer cells in cultures. Thus, it has been related to cellular and molecular mechanisms of the antiaging and antitumor effects [74]. The reduced expression of the CYP27A1 gene observed in this study could lead to reduction in primary bile acid synthesis, reducing its antitumor effects.

CYPs play key roles in steroid biosynthesis, the pathway responsible for cholesterol synthesis. In this pathway, vitamin D3 is converted to calcidiol by the CYP2R1 enzyme and subsequently in calcitriol $\left(1,25[\mathrm{OH}]_{2} \mathrm{D}_{3}\right)$, the circulating form of vitamin D3 [75], by the CYP27B1 enzyme [47]. Calcitriol can modulate the expression of the CYP2R1 gene in OSCC, and thus the vitamin $\mathrm{D}$ analogs can be potential therapeutic agents in the control of OSCC progression [31]. In our study, the reduced expression of the CYP2R1 gene in OSCC could be explained by vitamin $\mathrm{D}$ deficiency in patients with cancer, evidenced by literature [76-78], although vitamin $D$ has not been quantified in these patients.

In addition to vitamin $\mathrm{D}$, other steroid lipids from the steroid hormones biosynthesis [47], such as testosterone, androsterone, estrogen, and cortisone, can regulate cell signaling to control several physiological functions $[47,79]$.

Testosterone is formed from dehydroepiandrosterone (DHEA) in a CYP2E1-mediated reaction [47]. One study has shown an inhibitory potential of the DHEA compound on chemoprophylaxis to chemical carcinogens and mutations [80]. In our study, the reduced expression of the CYP2E1 gene could be related to OSCC development, possibly by reduction of DHEA and its function as an inhibitor of carcinogens.

Also acting in linoleic acid metabolism, the CYP2E1 and CYP2J2 enzymes use linoleate compound (linoleic acid) as a precursor to generate arachidonate, which can be directed to the metabolism of AA [47]. In our study, the reduced expression of CYP2E1 and CYP2J2 genes in OSCC could result in increased levels of linoleic acid. This is in agreement with the findings about the effect of diacylglycerol oil (composed of linoleic acid $46.6 \%$ ) in transgenic rats carrying c-Ha-ras 
proto-oncogene human. This study showed that the increase of linoleic acid can promote oral cancer development [81].

In addition to catalyzing the oxidation of endogenous chemical components such as fatty acids (arachidonic-AA and linoleic), steroid hormones (testosterone), liposoluble vitamins (retinol and vitamin D3), and bile acid, CYP450 also metabolizes various chemical xenobiotics including drugs, environmental carcinogens, and amines [82].

In the oxidative biotransformation of xenobiotics, including drugs and other lipophilic exogenous compounds [83], CYP acts in Phase I, catalyzing the oxidation of substrates [84] and promoting metabolic activation of chemical carcinogens through the actions of the CYP2E1 [85], CYP4B1, and CYP4F12 enzymes [47, 52, 86]. Although our findings have demonstrated reduced expression of CYP2E1, CYP4B1, and CYP4F12 genes in OSCC, we cannot report modification of their enzymatic activity, since even at low concentrations, as observed in this study, these enzymes can generate activated carcinogenic compounds.

In addition to CYP, the Monoamine Oxidase B enzyme (MAOB) also acts in drug metabolism. MAOB is also an important flavoenzyme in regulating the metabolic degradation of serotonin in nerve tissue or the target tissues [51]. MAOB acts, as well, in the serotonergic synapse, along with the ALOX12, CYP2J2, and CYP4X1 enzymes [47]. Decreased activity of MAO can interfere with the effects of antidepressant drugs in serotonergic neurotransmission [87] by means of increasing serotonin, which acts as a mediator of cell division [88]. The inhibition of this enzyme has been associated with increased serotonin levels and consequent increase of cell proliferation in colon tumors [89]. Our findings regarding MAOB-reduced expression in OSCC corroborate with the results obtained by Chen and et al., in pharyngeal cancer [90].

Another important MAOB-associated mechanism for carcinogenesis is the metabolism of amino acids such as tyrosine, glycine, serine, threonine, tryptophan, histidine, arginine, proline, and phenylalaninein [47]. Amino acids have a dual role in cellular metabolism, as precursors for protein synthesis and as intermediate metabolites in other biosynthetic reactions. Disruption of these processes is generally observed in cancer, and serine and glutamine are the most common amino acids used by tumor cells [91]. Amino acids are used in the machinery of mTOR (mechanistic target of rapamycin), which is also altered in cancer [78]. The reduced expression pattern of the MAOB gene in this study could be associated with alteration in the metabolism of amino acids as well as influencing the machinery mTOR and thereby contributing to development of OSCC.

$\mathrm{MAOB}$ also acts by catalyzing the oxidative deamination of biogenic monoamines and exogenous compounds [49, 92], generating hydrogen peroxide $\left(\mathrm{H}_{2} \mathrm{O}_{2}\right)$ and acetaldehyde, which are able to induce cell death in cultures of various human tumor cell lines. $\mathrm{H}_{2} \mathrm{O}_{2}$ can directly interact with molecules and endogenous structures, resulting in oxidative stress [92]. In addition to MAOB, CYP450 is also involved in oxidative stress [9] and production of reactive oxygen species (ROS) [93-95], which can lead to DNA damage and mutation, resulting in proto-oncogene activation or tumor suppressor genes inactivation and promoting cancer [96]. In addition, an oxidative/nitrosative stress study suggested that it could play a significant role in oral cavity cancer and that curative resection is effective in alleviating this oxidative/nitrosative burden, since tumors form the major source of oxidants [97].

ROS are derived from the consumption of a nicotinamide adenine dinucleotide phosphate (NADPH) cofactor by CYP450 microsomal [24, 96, 98, 99]. In steroid biosynthesis, CYP2R1 and CYP27B1 enzymes can regulate oxidative stress by calcitriol synthesis, which acts as a hormone interfering in levels of ROS through regulation of the expression of regulator genes belonging to the antioxidant system [78].

Furthermore, evidence indicates that ROS production induces VEGF-A (Vascular endothelial growth factor A) gene expression [100], related to angiogenesis, and can promote the metastatic growth of tumor cells [101]. Moreover, VEGF is necessary to transport polyunsaturated fatty acids to endothelial cells. Thus, a decrease in VEGF levels can reduce the formation of anti-inflammatory and angiogenic factors, which participate in processes such as oxidative stress, endothelial dysfunction, insulin resistance, and production of prostacyclin [102] (generated by PTGIS), an important factor in endothelial vasodilation [103].

Therefore, reduced expression of genes encoding MAOB, CYP2E1 CYP2R1, PTGIS, and CYP27B1, which are involved in oxidative stress, could modulate the intracellular balance of ROS/antioxidants and the risk for OSCC development.

\section{Conclusions}

The differential expression pattern of the studied genes could modulate metabolisms that contribute to oral squamous cell carcinoma development. These metabolisms are involved in processes such as inflammation, inhibition of carcinogenic agents, lipid oxidation, oxidative stress, autophagy, apoptosis, cell differentiation and proliferation, tumorigenesis, angiogenesis, and vasodilation, which contribute to migration and invasion of cancer cells in tissues of different histological type, promoting metastasis. An important metabolic pathway involved in the OSCC tumorigenesis evidenced in this study is the arachidonic acid metabolism, in which the PTGIS enzyme participates, presenting more significant differential expression in tumors. Further investigations, with expansion of the sample group, are necessary to establish the relationship between the expression pattern of the investigated genes and oral squamous cell carcinoma.

\section{Data Availability}

All data generated or analysed during this study are included in this published article; if necessary the datasets used and/or analysed during the current study are available from the corresponding author on reasonable request.

\section{Conflicts of Interest}

The authors declare that there is no conflict of interest regarding the publication of this paper. 


\section{Acknowledgments}

The authors are grateful to support of FAMERP/FUNFARME. They are also grateful for assistances in IHQ evaluate by Heloisa Cristina Caldas. The authors are grateful for the financial support of the "Fundação de Amparo à Pesquisa do Estado de São Paulo"-FAPESP process number 2013/049236, to "Coordenação de Aperfeiçoamento de Pessoal de Nível Superior"-CAPES, "Conselho Nacional de Desenvolvimento Científico e Tecnológico”-CNPq (310582/2014-8).

\section{References}

[1] R. Mogilner and H. Elishoov, "Oral cancer-not only a disease of elder patients with risk factors," Refuat Hapeh Vehashinayim, vol. 32, no. 1, Article ID 25799794, pp. 42-48, 2015.

[2] "Instituto Nacional do Câncer (INCA) Estimativa 2018, Incidência de Câncer no Brasil," Ministério da Saúde, INCA, Jose Alencar Gomes da Silva, http://www.inca.gov.br.

[3] D. Young, C. C. Xiao, B. Murphy, M. Moore, C. Fakhry, and T. A. Day, "Increase in head and neck cancer in younger patients due to human papillomavirus (HPV)," Oral Oncology, vol. 51, no. 8, pp. 727-730, 2015.

[4] E. Benson, R. Li, D. Eisele, and C. Fakhry, "The clinical impact of HPV tumor status upon head and neck squamous cell carcinomas," Oral Oncology, vol. 50, no. 6, pp. 565-574, 2014.

[5] O. Hershkovich, I. Shafat, and R. M. Nagler, "Age-related changes in salivary antioxidant profile: possible implications for oral cancer," Journals of Gerontology Series A Biological Sciences and Medical Sciences, vol. 62, no. 4, pp. 361-366, 2007.

[6] J. Liu and Z. Wang, "Increased Oxidative Stress as a Selective Anticancer Therapy," Oxidative Medicine and Cellular Longevity, vol. 2015, Article ID 294303, 12 pages, 2015.

[7] S. S. Patel, K. A. Shah, M. J. Shah, K. C. Kothari, and R. M. Rawal, "Cancer stem cells and stemness markers in oral squamous cell carcinomas," Asian Pacific Journal of Cancer Prevention, vol. 15, no. 20, pp. 8549-8556, 2014.

[8] E. C. Pavarino, A. Russo, A. L. S. Galbiatti et al., "Glutathione: biosynthesis and mechanism of action," in Glutathione: biochemistry, mechanisms of action and biotechnological implications, N. Labrou and E. Flemetakis, Eds., pp. 7-10, Nova Science Publishers Inc, New York, 2013.

[9] K. Linhart, H. Bartsch, and H. K. Seitz, "The role of reactive oxygen species (ROS) and cytochrome P-450 2E1 in the generation of carcinogenic etheno-DNA adducts," Redox Biology, vol. 3, pp. 56-62, 2014.

[10] P. P. Singh, A. Chandra, F. Mahdi, A. Roy, and P. Sharma, "Reconvene and reconnect the antioxidant hypothesis in human health and disease," Indian Journal of Clinical Biochemistry, vol. 25, no. 3, pp. 225-243, 2010.

[11] K. H. Janbaz, M. I. Qadir, H. T. Basser, T. H. Bokhari, and B. Ahmad, "Review Risk for oral cancer from smokeless tobacco," Współczesna Onkologia, vol. 3, pp. 160-164, 2014.

[12] N. Roswall and E. Weiderpass, "Alcohol as a Risk Factor for Cancer: Existing Evidence in a Global Perspective," Journal of Preventive Medicine \& Public Health, vol. 48, no. 1, pp. 1-9, 2015.

[13] E. M. Varoni, G. Lodi, and M. Iriti, "Ethanol versus phytochemicals in wine: Oral cancer risk in a light drinking perspective," International Journal of Molecular Sciences, vol. 16, no. 8, pp. 17029-17047, 2015.
[14] J. M. Biselli, R. C. Leal, M. T. Ruiz et al., "Polimorfismos GSTT1 e GSTM1 em indivíduos tabagistas com carcinoma espinocelular de cabeça e pescoço," Brazilian Journal of Otorhinolaryngology, vol. 72, no. 5, pp. 654-658, 2006.

[15] E. M. Goloni-Bertollo, J. M. Biselli, L. C. Corrêa et al., "Avaliação da influência da nulidade dos genótipos GSTT1 e GSTM1 na carcinogênese em cabeça e pescoço," Revista da Associação Médica Brasileira, vol. 52, no. 5, pp. 365-368, 2006.

[16] C. V. Leme, L. S. Raposo, M. T. Ruiz et al., "Análise dos genes GSTM1 e GSTT1 em pacientes com câncer de cabeça e pescoço," Revista da Associação Médica Brasileira, vol. 56, no. 3, pp. 299303, 2010.

[17] C. A. Sanches, A. L. Werneck, and P. C. Silveira, Avaliação de polimorfismos de genes metabolizadores de xenobióticos em pacientes com câncer de cabeça e pescoço. Dissertation (masters), São José do Rio Preto: Faculdade de Medicina de São José do Rio Preto, 2011.

[18] M. Hernando-Rodriguez, N. Rey-Barja, X. Marichalar-Mendia, M. J. Rodriguez-Tojo, A. Acha-Sagredo, and J. M. AguirreUrizar, "Role of cytochrome P-450 genetic polymorphisms in oral carcinogenesis," Journal of Oral Pathology \& Medicine, vol. 41, no. 1, pp. 1-8, 2012.

[19] N. M. Cury, A. Russo, A. Ĺ. S. Galbiatti et al., "Polymorphisms of the CYP1A1 and CYP2E1 genes in head and neck squamous cell carcinoma risk," Molecular Biology Reports, vol. 39, no. 2, pp. 1055-1063, 2012.

[20] A. Russo, P. R. Francelin, A. L. S. Galbiatti et al., "Association between GSTP1, GSTM1 and GSTT1 polymorphisms involved in xenobiotic metabolism and head and neck cancer development," Molecular Biology Reports, vol. 40, no. 7, pp. 4181-4188, 2013.

[21] R.-E. Go, K.-A. Hwang, and K.-C. Choi, "Cytochrome P450 1 family and cancers," The Journal of Steroid Biochemistry and Molecular Biology, vol. 147, pp. 24-30, 2015.

[22] H. Szaefer, M. Cichocki, and A. Majchrzak-Celińska, "New cytochrome $\mathrm{P} 450$ isoforms as cancer biomarkers and targets for chemopreventive and chemotherapeutic agents," Postepy Higieny i Medycyny Doswiadczalnej, vol. 67, pp. 709-718, 2013.

[23] X. Xu, X. A. Zhang, and D. W. Wang, "The roles of CYP450 epoxygenases and metabolites, epoxyeicosatrienoic acids, in cardiovascular and malignant diseases," Advanced Drug Delivery Reviews, vol. 63, no. 8, pp. 597-609, 2011.

[24] S. Zelasko, W. R. Arnold, and A. Das, "Endocannabinoid metabolism by cytochrome P450 monooxygenases," Prostaglandins \& Other Lipid Mediators, vol. 116-117, pp. 112-123, 2015.

[25] S. Boccia, G. Cadoni, F. A. Sayed-Tabatabaei et al., "CYP1A1, CYP2E1, GSTM1, GSTT1, EPHX1 exons 3 and 4, and NAT2 polymorphisms, smoking, consumption of alcohol and fruit and vegetables and risk of head and neck cancer," Journal of Cancer Research and Clinical Oncology, vol. 134, no. 1, pp. 93100, 2008.

[26] I. A. Pikuleva and M. R. Waterman, "Cytochromes P450: Roles in diseases," The Journal of Biological Chemistry, vol. 288, no. 24, pp. 17091-17098, 2013.

[27] G. Cadoni, S. Boccia, L. Petrelli, P. Di Giannantonio, D. Arzani, and A. Giorgio, "A review of genetic epidemiology of head and neck cancer related to polymorphisms in metabolic genes, cell cycle control and alcohol metabolism," Acta Otorhinolaryngol Ital, vol. 32, no. 1, Article ID 22500060, pp. 1-11, 2012.

[28] T. Lynch and A. Price, "The effects of cytochrome P450 metabolism on drug response, interactions, and adverse effects., 
Am Fam Phys," in The effects of cytochrome P450 metabolism on drug response, pp. 76-391, 76, 391-6, 2007.

[29] F. Oesch, E. Fabian, K. Guth, and R. Landsiedel, "Xenobioticmetabolizing enzymes in the skin of rat, mouse, pig, guinea pig, man, and in human skin models," Archives of Toxicology, vol. 88, no. 12, pp. 2135-2190, 2014.

[30] P. H. Hwang, L. Lian, and A. I. Zavras, "Alcohol intake and folate antagonism via CYP2E1 and ALDH1: Effects on oral carcinogenesis," Medical Hypotheses, vol. 78, no. 2, pp. 197-202, 2012.

[31] K. Sundaram, Y. Sambandam, E. Tsuruga, C. L. Wagner, and S. V. Reddy, "1 $\alpha, 25$-Dihydroxyvitamin D3 Modulates CYP2R1 Gene Expression in Human Oral Squamous Cell Carcinoma Tumor Cells," Hormones and Cancer, vol. 5, no. 2, pp. 90-97, 2014.

[32] A. van Zyl and BK. Bunn, "Clinical features of oral cancer," SADJ, vol. 67, no. 10, Article ID 23957097, pp. 566-569, 2012.

[33] G. S. Lessa, De Moraes E. D., Carvalho E. C., and I. Agra, "Quimioterapia nos tumors de cabeça e pescoço," in Guimarães, $J R Q$, editors. Manual de oncologia, pp. 1333-1334, São Paulo: Editora BBS, 3rd edition, 2008.

[34] L. Sobin, M. K. Gospodarowicz, and C. Wittekind, TNM Classification of Malignant Tumours, UICC, 7th edition, 2009.

[35] S. B. Edge, D. R. Byrd, C. C. Compton, A. G. Fritz, F. L. Greene, and A. Trotti, American Joint Committee on Cancer (AJCC): Cancer Staging Manual, Springer, New York, 7th edition, 2009.

[36] M. R. Pillai, A. Phanidhara, A. L. Kesari, P. Nair, and M. K. Nair, "Cellular manifestations of human papillomavirus infection in the oral mucosa," J Surg Oncol, vol. 71, no. 1, pp. 10-1002, 1999.

[37] P. T. Hennessey, W. H. Westra, and J. A. Califano, "Human papillomavirus and head and neck squamous cell carcinoma: Recent evidence and clinical implications," Journal of Dental Research, vol. 88, no. 4, pp. 300-306, 2009.

[38] J. Sink and D. Kademani, "Maxillofacial oncology at the University of Minnesota: treating the epidemic of oral cancer," Northwest Dent, vol. 90, no. 3, Article ID 21736188, pp. 13-16, 2011.

[39] G. C. Blitzer, M. A. Smith, S. L. Harris, and R. J. Kimple, "Review of the clinical and biologic aspects of human papillomaviruspositive squamous cell carcinomas of the head and neck," International Journal of Radiation Oncology . Biology . Physics, vol. 88, no. 4, pp. 761-770, 2014.

[40] Instituto Nacional de Ciência e Tecnologia das Doenças Associadas ao Papilomavír $\mu$ s do HPV (INCT-HPV). 2015. www.incthpv.org.br/SobreHpv/Default.aspx.

[41] de Oliveira C. M., I. G. Bravo, and G. Mlnd, "Inter- and intrahost HPV16 genetic diversity in patients with invasive cervical cancer [abstract]," in Proceedings of the 29th International Papillomavirus Conference and Public Health \& Clinical Workshops, vol. 152, Washington State Convention Center, Seattle, Washington, USA, 2014.

[42] C. Centrone, de Oliveira C. M., A. Fregnani JH Longatto-Filho, J. Carvalho, and J. E. Levi, "Detection of HPV DNA in plasma samples of women with invasive cervical cancer (ICC) from Sao Paulo, Brazil," in Proceedings of the 29th International Papillomavirus Conference and Public Health \& Clinical Workshops, vol. 20, pp. 03-03, Washington State Convention Center, Seattle, Washington, USA, 2014.

[43] J. Vandesompele, K. De Preter, F. Pattyn et al., "Accurate normalization of real-time quantitative RT-PCR data by geometric averaging of multiple internal control genes," Genome Biology, vol. 3, no. 7, Article ID RESEARCH0034, 2002.
[44] P. M. B. Chicote, Expressão de isofromas do gene VEGF e de proteínas reguladoras de splicing em carcinoma espinocelular de cabeça e pescoço. Thesis (doctoral), Faculdade de Medicina de São José do Rio Preto, São José do Rio Preto, 2011.

[45] JM. Biselli, Expressão diferencial de microRNAs em células monocelulares do sangue periférico de crianças com syndrome de Down Thesis (doctoral), Faculdade de Medicina de São José do Rio Preto, São José do Rio Preto, 2011.

[46] K. J. Livak and T. D. Schmittgen, "Analysis of relative gene expression data using real-time quantitative PCR and the 2$\Delta \Delta$ Ct method," Methods, vol. 25, no. 4, pp. 402-408, 2001.

[47] Kyoto Encyclopedia of Genes and Genomes (KEGG). http://www.genome.jp/kegg.

[48] Seach Tool for the Retrieval of Interacting Genes/Proteins Information (STRING). http://string-db.org/.

[49] National Center for Biotechnology (NCBI). http://www .ncbi.nlm.nih.gov/gene.

[50] GeneCards ${ }^{\circledR}$ : The Human Gene Database. http://www.genecards.org/.

[51] Descritores em Ciências da Saúde (DeCS). http://decs.bvs.br/.

[52] Protein knowledgebase (UniProtKB). http://www.uniprot.org/ help/uniprotkb.

[53] European Molecular Biology Laboratory - The European Bioinformatic Institute (EMBL-EBI). http://www.ebi.ac.uk/.

[54] Y. Benjamini and Y. Hochberg, "Controlling the false discovery rate: a practical and powerful approach to multiple testing," Journal of the Royal Statistical Society B: Methodological, vol. 57, no. 1, pp. 289-300, 1995.

[55] K. Kjærheim, M. Gaard, and A. Andersen, "The role of alcohol, tobacco, and dietary factors in upper aerogastric tract cancers: A prospective study of 10,900 Norwegian men," Cancer Causes \& Control, vol. 9, no. 1, pp. 99-108, 1998.

[56] M. Takiguchi, W. S. Darwish, Y. Ikenaka, M. Ohno, and M. Ishizuka, "Metabolic activation of heterocyclic amines and expression of CYP1A1 in the tongue," Toxicological Sciences, vol. 116, no. 1, pp. 79-91, 2010.

[57] C. Menna, F. Olivieri, A. Catalano, and A. Procopio, "Lipoxygenase inhibitors for cancer prevention: Promises and risks," Current Pharmaceutical Design, vol. 16, no. 6, pp. 725-733, 2010.

[58] X. Chen, S. Wang, N. Wu, and C. S. Yang, "Leukotriene A4 hydrolase as a target for cancer prevention and therapy," Current Cancer Drug Targets, vol. 4, no. 3, pp. 267-283, 2004.

[59] B. Samuelsson, "Arachidonic acid metabolism: Role in inflammation. Zeitschrift fur Rheumatologie," in Arachidonic acid metabolism: Role in inflammation. Zeitschrift fur Rheumatologie 1991, p. 059, 50, 3-6, 1991.

[60] C. Chen and D. W. Wang, "CYP epoxygenase derived EETs: From cardiovascular protection to human cancer therapy," Current Topics in Medicinal Chemistry, vol. 13, no. 12, pp. 14541469, 2013.

[61] M.-C. Cathcart, J. V. Reynolds, K. J. O’Byrne, and G. P. Pidgeon, "The role of prostacyclin synthase and thromboxane synthase signaling in the development and progression of cancer," Biochimica et Biophysica Acta (BBA) - Reviews on Cancer, vol. 1805, no. 2, pp. 153-166, 2010.

[62] M.-T. Wang, K. V. Honn, and D. Nie, "Cyclooxygenases, prostanoids, and tumor progression," Cancer and Metastasis Reviews, vol. 26, no. 3-4, pp. 525-534, 2007.

[63] M. Camacho, Z. Piñeiro, S. Alcolea et al., "Prostacyclin-synthase expression in head and neck carcinoma patients and its prognostic value in the response to radiotherapy," The Journal of Pathology, vol. 235, no. 1, pp. 125-135, 2015. 
[64] M. Nakano, C. M. Lockhart, E. J. Kelly, and A. E. Rettie, "Ocular cytochrome P450s and transporters: Roles in disease and endobiotic and xenobiotic disposition," Drug Metabolism Reviews, vol. 46, no. 3, pp. 247-260, 2014.

[65] D. Wang and R. N. Dubois, "Eicosanoids and cancer," Nature Reviews Cancer, vol. 10, no. 3, pp. 181-193, 2010.

[66] B. Baer and A. Rettie, "CYP4B1: an enigmatic P450 at the interface between xenobiotic and endobiotic metabolism," Drug Metabolism Reviews, vol. 38, no. 3, pp. 451-476, 2006.

[67] S. K. Chakrabarti, B. K. Cole, Y. Wen, S. R. Keller, and J. L. Nadler, "12/15lipoxygenase products induce inflammation and impair insulin signaling in 3T3-L1 adipocytes," Obesity (Silver Spring), vol. 17, pp. 1657-1663, 2009.

[68] S. E. Kleinstein, L. Heath, K. W. Makar et al., "Genetic variation in the lipoxygenase pathway and risk of colorectal neoplasia," Genes, Chromosomes and Cancer, vol. 52, no. 5, pp. 437-449, 2013.

[69] C. Liu and C. Montell, "Forcing open TRP channels: Mechanical gating as a unifying activation mechanism," Biochemical and Biophysical Research Communications, vol. 460, no. 1, pp. 22-25, 2015.

[70] R. Marincsák, B. Tóth, G. Czifra et al., "Increased expression of TRPV1 in squamous cell carcinoma of the human tongue," Oral Diseases, vol. 15, no. 5, pp. 328-335, 2009.

[71] A. Schweitzer, S. K. Knauer, and R. H. Stauber, "Nuclear receptors in head and neck cancer: Current knowledge and perspectives," International Journal of Cancer, vol. 126, no. 4, pp. 801-809, 2010.

[72] Z. Zhang, Y. Xu, Q. Xu, and Y. Hou, "PPAR $\gamma$ against tumors by different signaling pathways," Onkologie, vol. 36, no. 10, pp. 598601, 2013.

[73] M. Burotto and E. Szabo, "PPAR $\gamma$ in head and neck cancer prevention,” Oral Oncology, vol. 50, no. 10, pp. 924-929, 2014.

[74] A. Arlia-Ciommo, A. Piano, V. Svistkova, S. Mohtashami, and V. I. Titorenko, "Mechanisms underlying the anti-aging and antitumor effects of lithocholic bile acid," International Journal of Molecular Sciences, vol. 15, no. 9, pp. 16522-16543, 2014.

[75] R. P. Heaney, "Vitamin D in health and disease," Clinical Journal of the American Society of Nephrology, vol. 3, no. 5, pp. 1535-1541, 2008.

[76] X. Wu, T. Zhou, N. Cao, J. Ni, and X. Wang, "Role of vitamin D metabolism and activity on carcinogenesis," Oncology Research : Featuring Preclinical and Clinical Cancer Therapeutics, vol. 22, no. 3, pp. 129-137, 2015.

[77] M. Tomíška, Š. Novotná, L. Klvačová, J. Tůmová, and J. Andrea, "Vitamin D During Cancer Treatment," Klinicka Onkologie, vol. 28, no. 2, pp. 99-104, 2015.

[78] M. J. Berridge, "Vitamin D cell signalling in health and disease," Biochemical and Biophysical Research Communications, vol. 460, no. 1, pp. 53-71, 2015.

[79] C. Huang and C. Freter, "Lipid metabolism, apoptosis and cancer therapy," International Journal of Molecular Sciences, vol. 16, no. 1, pp. 924-949, 2015.

[80] S. Yang, Z. Fu, F. Wang, Y. Cao, and R. Han, "Anti-mutagenicity activity of dehydroepiandrosterone," Zhonghua Zhong Liu Za Zhi, vol. 24, no. 2, pp. 137-40, 12015034.

[81] H. Tsuda, M. Iigo, N. Takasuka et al., "Possible enhancing activity of diacylglycerol on 4-nitroquinoline 1-oxide induced carcinogenesis of the tongue in human c-Ha-ras proto-oncogene transgenic rats," Food and Chemical Toxicology, vol. 45, no. 6, pp. 1013-1019, 2007.
[82] T. Niwa, N. Murayama, and H. Yamazaki, "Oxidation of Endobiotics Mediated by Xenobiotic-Metabolizing Forms of Human Cytochrome P450," Current Drug Metabolism, vol. 10, no. 7, pp. 700-712, 2009.

[83] D. R. Nelson, “Cytochrome P450 nomenclature," Methods Mol Biol, pp. 2006-320, 2004.

[84] T. Oyama, N. Kagawa, N. Kunugita et al., "Expression of cytochrome P450 in tumor tissues and its association with cancer development," Frontiers in Bioscience, vol. 9, pp. 19671976, 2004.

[85] P. Anzenbacher and U. M. Zanger, Metabolism of Drugs and Other Xenobiotics, Wiley-VCH Verlag GmbH \& Co. KGaA, Weinheim, Germany, 2012.

[86] J. H. Jiang, W. H. Jia, H. D. Qin, H. Liang, Z. G. Pan, and Y. X. Zeng, "Expression of cytochrome P450 enzymes in human nasopharyngeal carcinoma and non-cancerous nasopharynx tissue," Ai Zheng, vol. 23, no. 6, p. 672, 2004 (Chinese).

[87] Z. Fisar, J. Hroudová, and J. Raboch, "Inhibition of monoamine oxidase activity by antidepressants and mood stabilizers," Neuro Endocrinol Lett, vol. 31, no. 5, pp. 645-56, 21200377.

[88] A. B. Steingart and M. Cotterchio, "Do antidepressants cause, promote, or inhibit cancers?" Journal of Clinical Epidemiology, vol. 48, no. 11, pp. 1407-1412, 1995.

[89] V. Van Noort, S. Schölch, M. Iskar et al., "Novel drug candidates for the treatment of metastatic colorectal cancer through global inverse gene-expression profiling," Cancer Research, vol. 74, no. 20, pp. 5690-5699, 2014.

[90] P.-H. Chen, B. Huang, T.-Y. Shieh et al., "The Influence of Monoamine Oxidase Variants on the Risk of Betel QuidAssociated Oral and Pharyngeal Cancer," The Scientific World Journal, vol. 2014, Article ID 183548, 8 pages, 2014.

[91] Z. Tsun and R. Possemato, "Amino acid management in cancer," Seminars in Cell \& Developmental Biology, vol. 43, pp. 22-32, 2015.

[92] E. Agostinelli, G. Arancia, L. Dalla Vedova et al., “The biological functions of polyamine oxidation products by amine oxidases: Perspectives of clinical applications," Amino Acids, vol. 27, no. 3-4, pp. 347-358, 2004.

[93] E. C. Friedberg and L. B. Meira, "Database of mouse strains carrying targeted mutations in genes affecting biological responses to DNA damage Version 7," DNA Repair, vol. 5, no. 2, pp. 189209, 2006.

[94] R. K. Gupta, A. K. Patel, R. Kumari et al., "Interactions between oxidative stress, lipid profile and antioxidants in breast cancer: a Case Control Study," Asian Pacific Journal of Cancer Prevention, vol. 13, no. 12, pp. 6295-6298, 2012.

[95] R. K. Gupta, A. K. Patel, N. Shah et al., "Oxidative stress and antioxidants in disease and cancer: a review," Asian Pacific Journal of Cancer Prevention, vol. 15, no. 11, pp. 4405-4409, 2014.

[96] S. K. Choudhari, M. Chaudhary, A. R. Gadbail, A. Sharma, and S. Tekade, "Oxidative and antioxidative mechanisms in oral cancer and precancer: a review," Oral Oncology, vol. 50, no. 1, pp. 10-18, 2014.

[97] M. H. Rasheed, S. S. Beevi, R. Rajaraman, and S. J. C. Bose, "Alleviation of oxidative and nitrosative stress following curative resection in patient with oral cavity cancer," Journal of Surgical Oncology, vol. 96, no. 3, pp. 194-199, 2007.

[98] R. C. Zangar, D. R. Davydov, and S. Verma, "Mechanisms that regulate production of reactive oxygen species by cytochrome P450," Toxicology and Applied Pharmacology, vol. 199, no. 3, pp. 316-331, 2004. 
[99] V. J. Findlay, H. Tapiero, and D. M. Townsend, "Sulfiredoxin: A potential therapeutic agent?" Biomedicine \& Pharmacotherapy, vol. 59, no. 7, pp. 374-379, 2005.

[100] T. C. Chen, T. Sakaki, K. Yamamoto, and A. Kittaka, “The roles of cytochrome P450 enzymes in prostate cancer development and treatment," Anticancer Res, vol. 32, no. 1, Article ID 22213318, pp. 291-298, 2012.

[101] S. Saeidnia and M. Abdollahi, "Antioxidants: friends or foe in prevention or treatment of cancer: the debate of the century," Toxicology and Applied Pharmacology, vol. 271, no. 1, pp. 49-63, 2013.

[102] U. N. Das, "Cytokines, angiogenic, and antiangiogenic factors and bioactive lipids in preeclampsia," Nutrition Journal, vol. 31, no. 9, pp. 1083-1095, 2015.

[103] J. K. Limberg, J. W. Harrell, R. E. Johansson et al., "Microvascular function in younger adults with obesity and metabolic syndrome: role of oxidative stress," American Journal of PhysiologyHeart and Circulatory Physiology, vol. 305, no. 8, pp. H1230H1237, 2013. 


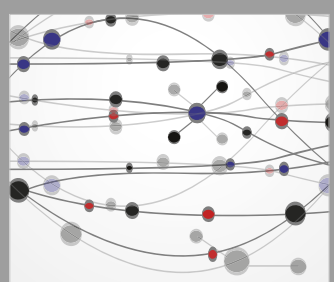

The Scientific World Journal
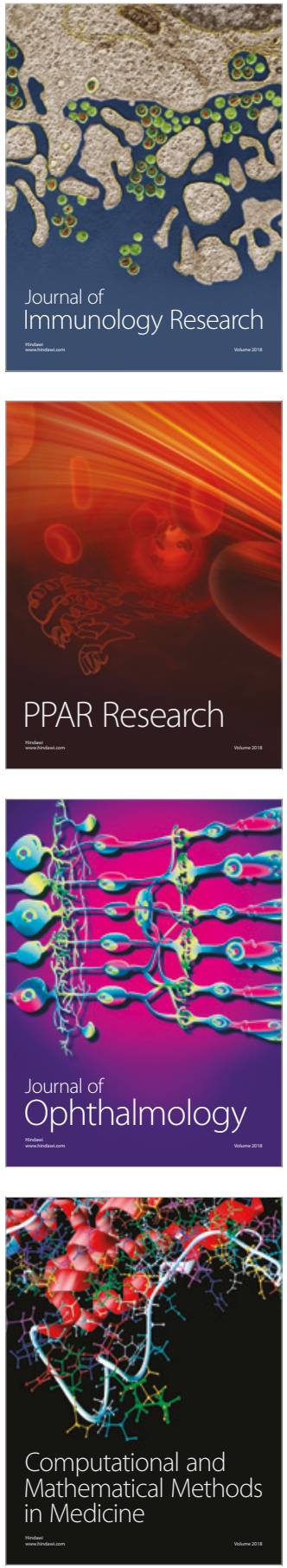

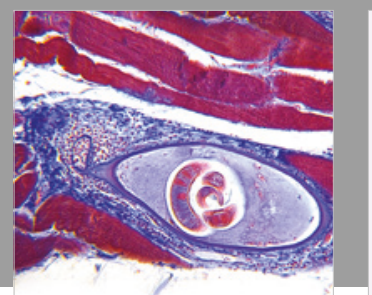

Gastroenterology Research and Practice

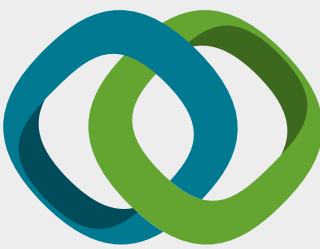

\section{Hindawi}

Submit your manuscripts at

www.hindawi.com
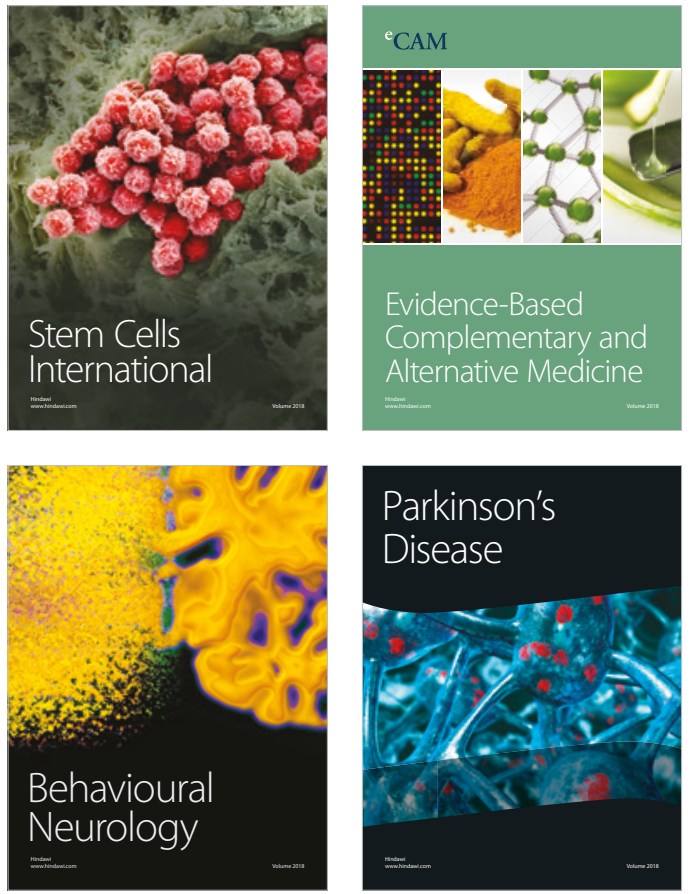

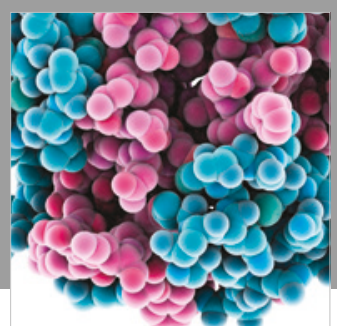

ournal of

Diabetes Research

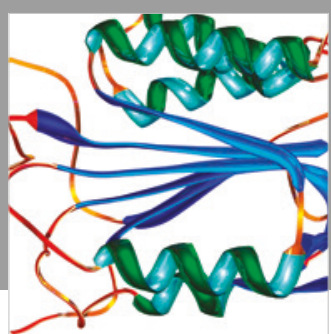

Disease Markers
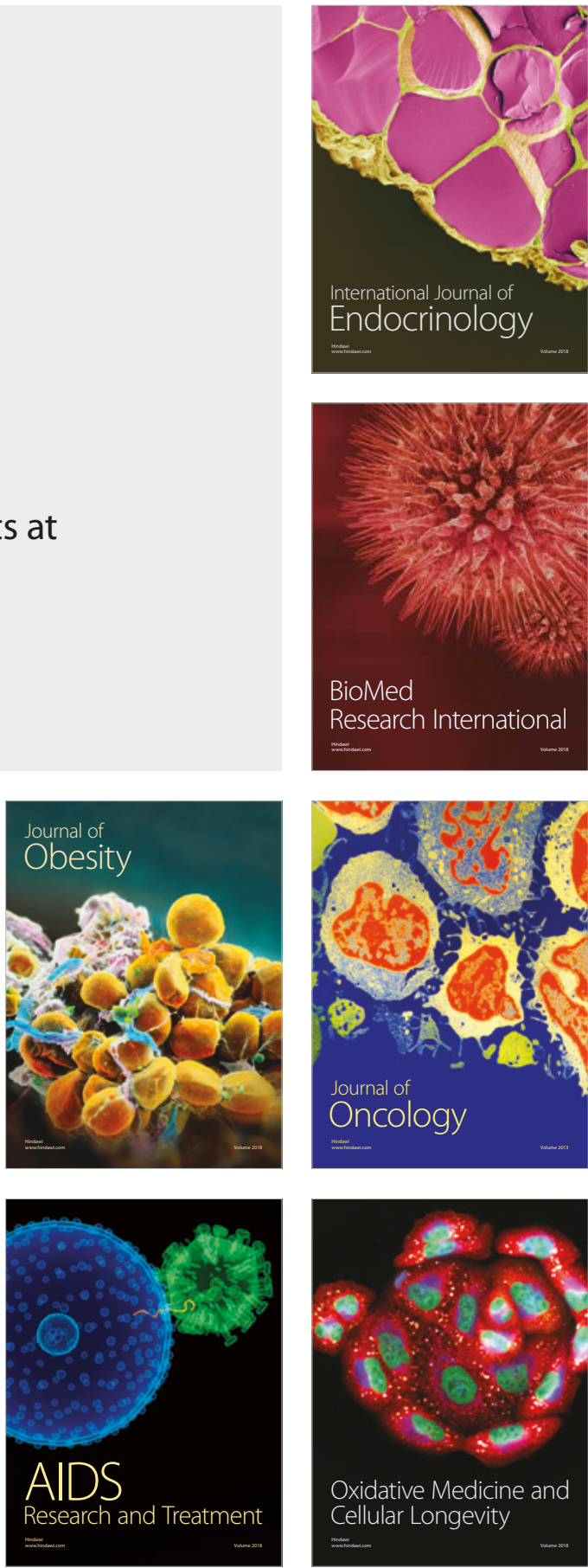